\title{
Model Pembelajaran Missouri Mathematics Project Terhadap Kemampuan Pemecahan Masalah Matematis Ditinjau dari Self Confidence Siswa
}

\author{
${ }^{1}$ Hartono, ${ }^{2}$ Niasika Nurul Huda, ${ }^{3}$ Iwit Prihatin \\ 1,2,3Program Studi Pendidikan Matematika, FMIPATEK, IKIP PGRI Pontianak, Indonesia \\ 2Email: niasiskanh.ns@gmail.com
}

\begin{abstract}
The purpose of this research, to see the difference between the model of Missouri Mathematics Project learning and conventional learning on mathematical problem-solving abilities in terms of students' self-confidence. The method used in this research is an experimental with kind of a Quasi-Experimental, and the research design is a $2 \times 3$ factorial design. The population in this study were all students of class XI MIPA of SMA Negeri 6 Pontianak consist of four classes, with class XI MIPA III and XI MIPA IV samples selected by the Cluster Random Sampling technique. Based on the analysis of variance of two paths with unequal cells it is concluded that: 1) The Missouri Mathematics Project learning model provides better mathematical problem-solving abilities compared to conventional learning in the matrix material. 2) Students who have high, medium and low self-confidence have no difference in the ability to solve mathematical problems in the matrix material. 3) In each learning model, students with high, medium and low self-confidence do not provide differences in mathematical problem solving between self-confidence found in themselves. 4) At each level of students' self-confidence, the Missouri Mathematics Project learning model provides better mathematical problem-solving skills than conventional learning.
\end{abstract}

Keyword: Missouri Mathematics Project, mathematical problem-solving abilities, Self-Confidence

\begin{abstract}
Abstrak: Tujuan dari penelitian ini secara umum adalah untuk melihat perbedaan antara model pembelajaran Missouri Mathematics Project dan pembelajaran konvensional terhadap kemampuan pemecahan masalah matematis ditinjau dari self confidence siswa dalam materi matriks di kelas XI SMA Negeri 6 Pontianak. Metode yang digunakan dalam penelitian ini adalah metode eksperimen, dengan bentuk penelitian Quasi Experimental, dan rancangan penelitian adalah desain faktorial $2 \times 3$. Populasi dalam penelitian ini adalah seluruh siswa kelas XI MIPA SMA Negeri 6 Pontianak terdiri dari empat kelas, dengan sampel kelas XI MIPA III dan XI MIPA IV yang dipilih secara random menggunakan teknik Cluster Random Sampling. Berdasarkan analisis variansi dua jalan dengan sel tak sama disimpulkan bahwa: 1) Model pembelajaran Missouri Mathematics Project memberikan kemampuan pemecahan masalah matematis yang lebih baik dibandingkan pembelajaran konvensional dalam materi matriks. 2) Siswa yang memiliki self confidence tinggi, sedang dan rendah tidak terdapat perbedaan kemampuan pemecahan masalah matematis dalam materi matriks. 3) Pada masing-masing model pembelajaran, siswa dengan self confidence tinggi, sedang dan rendah tidak memberikan perbedaan pemecahan masalah matematis antara self confidence yang terdapat pada diri sendiri. 4) Pada setiap tingkat self confidence siswa, model pembelajaran Missouri Mathematics Project memberikan kemampuan pemecahan masalah matematis yang lebih baik dari pembelajaran konvensional.
\end{abstract}

Kata Kunci: Missouri Mathematics Project, Kemampuan Pemecahan Masalah Matematis, Self Confidence 


\section{PENDAHULUAN}

Matematika yang diberikan di sekolah sangat penting dalam upaya meningkatkan sumber daya manusia yang berkualitas. Matematika adalah salah satu ilmu dasar yang mempelajari peranan penting dalam berbagai aspek kehidupan, karena matematika merupakan ilmu universal yang mendasari perkembangan teknologi modern, mempunyai peran dalam berbagai disiplin dan mengembangkan daya pikir manusia (BSNP dalam Darma \& Sujadi, 2014: 110). Matematika merupakan alat yang efisien dan diperlukan oleh semua ilmu pengetahuan. Tanpa bantuan matematika semuanya tidak akan mendapat kemajuan yang berarti. Dengan demikian matematika memegang peranan penting bagi berlangsungnya perkembangan ilmu pengetahuan dan peradaban dunia.

Dalam pendidikan di indonesia, matematika merupakan salah satu mata pelajaran yang di ajarkan. Matematika merupakan ilmu yang bermanfaat salah satunya untuk memecahkan masalah dalam kehidupan sehari-hari. Seperti yang di ungkapkan Johar (Arismawati 2017: 10) bahwa dengan penguasaan matematika yang baik dapat membantu siswa menyelesaikan masalah sehari-hari.

Menurut NCTM (Hendriana, dkk, 2017: 44) menyatakan bahwa istilah pemecahan masalah mengandung tiga pengertian, yaitu: pemecahan masalah sebagai tujuan, sebagai proses dan sebagai keterampilan. Pertama pemecahan masalah sebagai suatu tujuan (goal) yang menekankan pada aspek mengapa pemecahan masalah matematis perlu diajarkan. Dalam hal ini pemecahan masalah bebas dari soal, prosedur, metode, atau materi matematika. Sasaran utama yang ingin dicapai adalah bagaimana cara menyelesaikan masalah untuk menjawab soal atau pertanyaan. Kedua, pemecahan masalah sebagai suatu proses diartikan sebagai suatu kegiatan aktif, yang meliputi: metode, strategi, prosedur, dan heuristik yang digunakan oleh siswa dalam menyelesaikan masalah hingga menemukan jawaban. Ketiga, pemecahan masalah sebagai suatu keterampilan dasar yang memuat dua hal yaitu: keterampilan umum yang harus dimiliki siswa untuk keperluan evaluasi di tingkat sekolah, dan keterampilan minimum yang perlu dikuasai siswa agar dapat menjalankan perannya dalam masyarakat.

Hal ini sejalan dengan Branca (Sadat 2016: 1) yang mengatakan bahwa pemecahan masalah matematik merupakan hal yang sangat penting sehingga menjadi tujuan umum pengajaran matematika, bahkan bisa dikatakan sebagai jantungnya matematika. Untuk itu, matematika sangat penting untuk dikuasai oleh siswa, khususnya tentang pemecahan masalah. Menurut Polya (Hendriana, dkk, 2017: 45) adapun indikator dalam mengembangkan kemampuan pemecahan masalah matematis ialah: a) Memahami masalah yang meliputi: mengidentifikasikan unsur yang diketahui, unsur yang ditanyakan, memeriksa kecukupan unsur untuk penyelesaian masalah. b) Merencanakan penyelesaian yang meliputi: mengaitkan unsur yang diketahui dan ditanyakan dan merumuskannya dalam bentuk model matematika masalah. c) Menyelesaikan masalah sesuai rencana yang meliputi: melaksanakan strategi penyelesaian, mengelaborasi dan melaksanakan perhitungan atau menyelesaikan model matematika. d) Melihat kembali/ menyimpulkan yang meliputi: menginterprestasi hasil terhadap masalah semula dan memeriksa kembali kebenaran solusi.

Berdasarkan uraian tersebut, maka perlu dicari model pembelajaran alternatif yang dapat meningkatkan kemampuan pemecahan masalah matematis siswa. Proses penyelesaian masalah dalam pembelajaran matematika dapat diterapkan dalam berbagai model dan metode pembelajaran. Menurut Arends (dalam Siswono, 2018: 78) model pembelajaran mengacu pada pendekatan pembelajaran yang digunakan, termasuk di dalamnya tujuan-tujuan pembelajaran, tahap-tahap dalam kegiatan pembelajaran, lingkungan pembelajaran, dan pengelolaan kelas. Istilah model pembelajaran mempunyai dua alasan penting, yaitu: 1) model berimplikasi pada sesuatu yang lebih luas daripada 
strategi, metode, atau struktur. Istilah model pembelajaran mencakup sejumlah pendekatan untuk pengajaran; dan 2) model pembelajaran berfungsi sebagai sarana komunikasi yang penting, apakah yang dibicarakan tentang mengajar di kelas, automobile atau praktik anak.

Salah satu model pembelajaran yang telah dikembangkan adalah model pembelajaran Missouri Mathematics Project sebagai suatu program yang dirancang untuk membantu guru secara efektif menggunakan latihan-latihan agar guru mampu membuat siswa mendapatkan perolehan yang menonjol dalam prestasinya (Grouws dalam Ansori \& Aulia, 2015: 50). Menurut Hendriana (2018: 124) model pembelajaran missouri mathematics project merupakan suatu desain pembelajaran matematika, yang memfasilitasi siswa dengan adanya suatu penugasan proyek yang diselesaikan secara individu dan kelompok yang berupa soal-soal latihan untuk mengaplikasikan ilmu yang diperoleh.

Menurut Tiasto \&Arliani (Isrok'atun, 2018: 125) model Missouri Mathematics Project memuat lima langkah, yaitu: 1) Pendahuluan/Review, 2) Pengembangan, 3) Latihan dengan Bimbingan Guru/Kerja Kooperatif. 4) Seatwork/Kerja Mandiri, 5) Penutup. Karakteristik model pembelajaran missouri mathematics project adalah adanya tugas proyek. Hal ini ditunjukkan dengan disajikannya suatu lembar tugas proyek matematika, yang berisi soal-soal latihan penerapan materi matematika yang harus diselesaikan oleh siswa. Pengerjaan tugas proyek tersebut dilakukan secara berkelompok. Kegiatan belajar kelompok ini memungkinkan munculnya berbagai ide dan pendapat siswa, dalam mengembangkan materi melalui soal matematika.

Disamping model pembelajaran tersebut, terdapat pengaruh lain yang mempengaruhi proses pembelajaran siswa terhadap kemampuan pemecahan masalah matematisnya. Satu diantaranya ialah dalam kegiatan pemecahan masalah seseorang harus memiliki keyakinan diri, keyakinan diri sangat berkaitan erat dengan kepercayaan diri. Pajares \& Miller (Hendriana, dkk, 2018: 198) mengemukakan bahwa "Self confidence atau kepercayaan diri menyentuh hampir semua aspek kehidupan manusia, dalam berfikir secara produktif, secara pesimis atau optimis, bagaimana mereka memotivasi diri, kerawanan akan stress dan depresi, dan keputusan yang dipilih.

Sadat (2016: 2) mengemukakan bahwa Self Confidence adalah pandangan atau perasaan positif seseorang terhadap dirinya dan keyakinan atas pengetahuan, kemampuan dan kapasitas dirinya untuk bisa menjalankan tugas atau menangani persoalan-persoalan hidupnya dengan hasil yang sangat baik. Kepercayaan diri merupakan komponen awal untuk dapat berinteraksi dengan baik dilingkungan sekitar. Kepercayaan diri setiap siswa itu berbeda. Seorang siswa yang memiliki kepercayaan diri tinggi ia lebih cenderung aktif, berani dan yakin akan kemampuan dirinya sendiri. dan itupun akan berpengaruh terhadap kemampuan dalam memecahkan suatu permasalahan.

Berdasarkan wawancara pada seorang guru matematika di SMA Negeri 6 Pontianak diperoleh informasi bahwa siswa kesulitan dalam memahami materi pelajaran matematik, kurangnya kemampuan dalam pemecahan masalah matematika, kurang aktifnya siswa dalam pembelajaran, serta siswa kurang memahami cara penyelesaian soal tapi tidak berani bertanya, sehingga saat diberikan tugas mereka sukar untuk mengerjakan tugas tersebut. Permasalahan yang ada pada kelas XI SMA Negeri 6 Pontianak, upaya yang bisa dilakukan untuk bisa mengatasi masalah ini adalah dengan menerapkan model pembelajaran yang tepat sehingga dapat memicu self confidence siswa dalam belajar serta dapat meningkatkan kemampuan pemecahan masalah matematis siswa dan pada akhirnya dapat meningkatkan kualitas belajar siswa di sekolah. Oleh karena itu, peneliti bermaksud mengadakan penelitian yang berkaitan dengan model pembelajaran missouri mathematics project dan pembelajaran konvensional dalam materi 
matriks. Peneliti menerapkan kedua model pembelajaran ini, untuk mengatasi permasalahan yang telah ditemukan.

Penelitian ini mempunyai tujuan untuk menentukan: 1) Manakah yang lebih baik antara model pembelajaran Missouri mathematic project atau model pembelajaran Konvensional. 2) Manakah yang lebih baik, kemampuan pemecahan masalah matematis siswa yang memiliki self confidence tinggi, sedang atau rendah. 3) Pada masing-masing model pembelajaran, manakah yang lebih baik kemampuan pemecahan masalah matematis antara siswa yang memiliki self confidence tinggi, sedang atau rendah. 4) Pada masing-masing self confidence, manakah yang lebih baik, kemampuaan pemecahan masalah matematis siswa yang diterapkan model pembelajaran missouri mathematics project atau Konvensional.

\section{METODE}

Metode penelitian yang digunakan pada penelitian ini adalah metode eksperimen. Penelitian ini dilaksanakan di SMA Negeri 6 Pontianak tahun pelajaran 2019/2020. Bentuk penelitian ini adalah penelitian eksperimen semu atau Quasi Eksperimental dengan desain faktorial $2 \times 3$. Penelitian ini diawali dengan menentukan populasi dan memilih sampel dari populasi yang ada. Materi pokok yang digunakan dalam penelitian ini adalah matriks. Populasi dalam penelitian ini adalah seluruh siswa kelas XI MIPA SMA Negeri 6 Pontianak tahun pelajaran 2019/2020.

Teknik pengambilan sampel adalah dengan Cluster Random Sampling sehingga sampel yang terpilih dalam penelitian ini adalah siswa kelas XI MIPA III (32 siswa) sebagai kelas eksperimen dan XI MIPA IV (33 siswa) sebagai kelas kontrol. Pada kelas eksperimen diberikan pembelajaran matematika yang mengacu pada Missouri Mathematics Project, sedangkan kelompok kontrol diberi pembelajaran matematika dengan pembelajaran konvensional. Pada akhir pembelajaran dilakukan tes yang menguji kemampuan pemecahan masalah matematis siswa. Evaluasi ini dilakukan di kelas kontrol dan eksperimen dengan soal yang sama. Soal evaluasi yang diberikan kepada kelas sampel adalah soal yang telah diuji coba. Data-data yang diperoleh di analisis sesuai dengan statistik yang sesuai.

Metode pengumpulan data pada penelitian ini menggunakan nilai ulangan harian, angket dan tes. Nilai ulangan harian digunakan untuk memperoleh data kemampuan awal siswa. Metode angket digunakan untuk memperoleh data self confidence siswa dan angket diberikan sebelum diberikan perlakuan model pembelajaran missouri mathematics project dan pembelajaran konvensional. Metode tes yang digunakan untuk memperoleh data kemampuan pemecahan masalah siswa yaitu tes bentuk uraian. Sebelum soal digunakan untuk mengukur kemampuan pemecahan masalah siswa, soal tersebut terlebih dahulu diuji cobakan. Uji coba soal tersebut digunakan untuk mengetahui validitas, reliabilitas, tingkat kesukaran, dan daya pembeda. Soal yang telah diuji cobakan kemudian digunakan untuk tes akhir pada kelas eksperimen dan kelas kontrol.

Sebelum melakukan eksperimen, dilakukan uji keseimbangan terhadap kemampuan awal matematika dengan menggunakan uji -t. Data kemampuan pemecahan masalah matematika dianalisis menggunakan analisis variansi dua jalan dengan sel tak sama. Sebelumnya terhadap data kemampuan awal maupun kemampuan pemecahan masalah matemtatis dilakukan uji prasyarat meliputi uji normalitas populasi menggunakan metode Lilifors dan uji homogenitas variansi populasi menggunakan metode barttlet. selanjutnya apabila hasil analisis variansi menunjukkan $H_{0}$ ditolak, dilakukan uji komparasi ganda dengan menggunakan metode Scheffe (Budiyono, 2009: 170 - 215). 


\section{HASIL DAN PEMBAHASAN}

\section{Data Kemampuan Awal Matematika dan Uji Keseimbangan}

Data kemampuan awal matematika peserta didik kelas eksperimen (Missouri Mathematics Project) dan kelas kontrol (konvensional) dilakukan uji prasyarat sebelum pelaksanaan penelitian. Hasil uji prasyarat diperoleh bahwa sampel berasal dari populasi yang berdistribusi normal dan mempunyai variansi yang homogen. Hasil uji keseimbangan menggunakan uji-t terhadap kemampuan awal matematika perserta didik disajikan dalam tabel 1 yaitu diperoleh simpulan bahwa populasi mempunyai kemampuan awal yang seimbang.

\section{Tabel 1. Rangkuman Uji Keseimbangan Kemampuan Awal}

\begin{tabular}{llcll}
\hline $\mathrm{Db}$ & $t_{\text {hitung }}$ & $t_{0,025 ; d b}$ & Keputusan Uji & Kesimpulan \\
\hline 63 & 0,129 & 1,998 & $H_{0}$ diterima & Seimbang \\
\hline
\end{tabular}

\section{Analisis Variansi Dua Jalan Dengan Sel Tak Sama}

Data yang digunakan dalam pengujian hipotesis adalah kemampuan pemecahan masalah matematis peserta didik dalam materi matriks (Tabel 2). Hasil uji prasyarat diperoleh simpulan bahwa sampel berasal dari populasi yang berdistribusi normal dan mempunyai variansi yang homogen. Berikut disajikan hasil analisis variansi dua jalan dengan sel tak sama.

Tabel 2. Rangkuman Analisis Variansi Dua Jalan Dengan Sel Tak Sama

\begin{tabular}{|c|c|c|c|c|c|c|}
\hline $\begin{array}{c}\text { Sumber } \\
\text { Variasi }\end{array}$ & JK & Dk & RK & $\mathrm{F}_{o b s}$ & $F_{\text {Tabel }}$ & Keputusan \\
\hline $\begin{array}{c}\text { Model } \\
\text { Pembelajaran } \\
\text { (A) }\end{array}$ & 552,73 & 1 & 552,73 & 8,719 & 4,00 & $H_{0 A}$ ditolak \\
\hline $\begin{array}{c}\text { Self } \\
\text { Confidence (B) }\end{array}$ & 1761,17 & 2 & 880,585 & 1,271 & 3,15 & $\begin{array}{c}H_{0 B} \\
\text { diterima }\end{array}$ \\
\hline $\begin{array}{l}\text { Interaksi } \\
\text { (AB) }\end{array}$ & 87,928 & 2 & 43,964 & 0,694 & 3,15 & $\begin{array}{c}H_{0 A B} \\
\text { diterima }\end{array}$ \\
\hline $\begin{array}{l}\text { Galat } \\
\text { Total }\end{array}$ & 3740,201 & 59 & 63,393 & & & \\
\hline
\end{tabular}

Berdasarkan Tabel 2. Menunjukan bahwa $H_{0 A}$ ditolak. Hal ini berarti terdapat perbedaan kemampuan pemecahan masalah matematis antara siswa yang menggunakan model pembelajaran Missouri Mathematics Project dan siswa yang menggunakan pembelajaran konvensional. Dengan kata lain ada pengaruh model pembelajaran dengan pemecahan masalah matematis siswa, karena $H_{0 A}$ ditolak, untuk membandingkan kedua pembelajaran cukup dilihat dari rataan marginalnya saja.

Sementara itu, $H_{O B}$ diterima. Hal ini berarti tidak ada interaksi pada masing-masing self confidence terhadap kemampuan pemecahan masalah matematis siswa, tidak ada perbedaan kemampuan pemecahan masalah matematis antara siswa yang mempunyai self confidence tinggi, sedang dan rendah pada materi matriks. Dengan kata lain tidak terdapat pengaruh self confidence terhadap kemampuan pemecahan masalah matematis siswa. Karena $H_{0 B}$ diterima, uji komparasi ganda antar kolom (self confidence) tidak perlu dilakukan. 
Berdasarkan hasil analisis variansi dua jalan dengan sel tak sama, tidak diperlukan uji lanjut pasca anava yang dilakukan dengan menggunakan uji Scheffe. Dari hasil perhitungan diperoleh rataan marginal kemampuan pemecahan masalah matematis siswa disajikan dalam bentuk tabel 3.

Tabel 3. Deskripsi Data Rerata Sel dan Rerata Marginal

\begin{tabular}{lcccc}
\hline Kategori Model Pembelajaran & \multicolumn{3}{c}{ Tingkatan Self Confidence } & Rataan \\
\cline { 2 - 3 } & Tinggi & Sedang & Rendah & Marginal \\
\hline Missouri Mathematics Project & 85,4 & 78,067 & 70,714 & 78,060 \\
Konvensional & 76,273 & 74,769 & 65,111 & 72,051 \\
Rataan Marginal & 80,837 & 76,418 & 67,913 & - \\
\hline
\end{tabular}

Karena $H_{0 A}$ ditolak, maka tidak perlu dilakukan uji komparasi rerata antar baris karena hanya terdapat dua model pembelajaran, jadi langsung dilihat pada rerata marginalnya. Berdasarkan Tabel 3. Rataan marginal untuk model pembelajaran missouri mathematics project yaitu $(78,060)$ lebih besar dari rataan marginal pembelajaran konvensional yaitu $(72,051)$, sehingga dapat disimpulkan bahwa kemampuan pemecahan masalah matematis dengan model pembelajaran missouri mathematics project lebih baik dari pada pembelajaran konvensional ditinjau dari self confidence siswa dalam materi matriks.

Hal ini menunjukkan adanya pengaruh model pembelajaran matematika terhadap kemampuan pemecahan masalah matematis siswa. Dalam hal ini, model pembelajaran missouri mathematics project lebih efektif dari pada pembelajaran konvensional dalam materi matriks. Hasil penelitian ini juga sesuai dengan hasil penelitian yang dilakukan oleh Murbarani (2015) yang mengemukakan model pembelajaran missouri mathematics project efektif terhadap kemampuan pemecahan masalah matematis siswa. Adanya keunggulan model missouri mathematics project dalam memberikan kemampuan pemecahan masalah matematis yang lebih baik daripada model pemebelajaran konvensional pada penelitian ini dikarenakan menurut Fauziah \& Sukasno (Isrok'atun, 2018: 124) model pembelajaran missouri mathematics project memberikan peluang kepada siswa untuk bekerja dalam kelompok, latihan terkontrol, dan mengaplikasikan pemahaman sendiri dengan cara bekerja mandiri dalam seatwork. Seperti yang dikemukakan oleh Lester \& Kroll (Hendriana, dkk, 2017: 44) masalah adalah suatu kondisi dimana seseorang atau sekelompok orang harus menghadapi suatu tugas yang tidak memiliki algoritma penyelesaian secara pasti dalam penyelesaiannya, sehingga dengan model missouri mathematics project siswa sudah terlatih melakukan pemecahan masalah.

Selain itu, hal ini mungkin disebabkan oleh banyak faktor, diantaranya yaitu siswa yang diberikan model pembelajaran missouri mathematics project saling membantu anggota kelompoknya berdiskusi secara sungguh-sungguh. Selain itu juga, unsur model pembelajaran missouri mathematics project dipersiapkan dengan baik terutama dalam penyusunan Rencana Pelaksanaan Pembelajaran (RPP), dan Lembar Kerja Siswa (Joyce \& Well dalam Sari, 2016: 24).

Karena $H_{0 B}$ diterima, uji komparasi ganda antar kolom (self confidence) tidak perlu dilakukan. Tidak ada perbedaan antara siswa yang memiliki self confidence tinggi, sedang dan rendah. Kemampuan pemecahan masalah adalah usaha untuk mencari jalan keluar dari masalah yang tak ada solusi secara langsung (Polya dalam Hendriana dkk, 2017: 44) 
kemudian Ruseffendi (Hendriana dkk, 2017: 44) menjelaskan masalah dapat dipecahkan jika memiliki pengetahuan prasyarat yang mendasari. Pemahaman akan pengetahuan prasyarat tidak sejalan dengan self confidence yang dimiliki siswa. Sadat (2016: 2) mengemukakan bahwa self confidence adalah pandangan atau perasaan positif seseorang terhadap dirinya dan keyakinan atas pengetahuan, kemampuan dan kapasitas dirinya untuk bisa menjalankan tugas atau menangani persoalan-persoalan hidupnya dengan hasil yang sangat baik.

Dari hasil perhitungan analisis variansi dua jalan dengan sel tak sama diperoleh $F_{o b s}=0,694<3,15=F_{\text {tabel }}$ maka $H_{0 A B}$ diterima sehingga tidak perlu dilakukan uji pasca anava. Denga diterimanya $H_{0 A B}$ berati tidak terdapat interaksi antara model pembelajaran dan self confidence siswa dalam materi matriks. Karena tidak terdapat interaksi antara model pembelajaran dan self confidence, maka perbandingan antara model pembelajaran missouri mathematics project dan konvensional untuk setiap self confidence siswa mengikuti perbandingan marginalnya. Dengan tidak adanya interaksi mengakibatkan tidak terdapat perbedaan kemampuan pemecahan masalah matematis siswa pada model pembelajaran missouri mathematics project dan pembelajaran konvensional pada masing-masing kategori self confidence dan tidak terdapat perbedaan kemampuan pemecahan masalah matematis siswa dengan self confidence tinggi, sedang dan rendah pada masing-masing model pembelajaran. Berani mengungkapkan pendapat dan memiliki dorongan untuk berprestasi merupakan salah satu indikator dalam Self Confidence menurut Hendriana, dkk (2017: 199), hal ini menunjukkan siswa yang memiliki self confidence tinggi akan berusaha untuk berprestasi akan tetapi kenyataannya tidak. Dikarenakan self confidence dalam kedua model pembelajaran yang diterapkan tidak menjadi daya dukung siswa dalam menyerap materi pembelajaran.

\section{SIMPULAN}

Berdasarkan pengolahan data dan pembahasan dapat diketahui bahwa penerapan model pembelajaran Missouri Mathematics Project dalam materi matriks ditinjau dari self confidence siswa kelas XI SMA Negeri 6 Pontianak memberikan dampak positif yang lebih baik dibandingkan dengan pembelajaran Konvensional, hal ini disebabkan proses pembelajarannya. Secara umum dapat disimpulkan sebagai berikut: a) Model pembelajaran Missouri Mathematics Project memberikan kemampuan pemecahan masalah matematis yang lebih baik daripada pembelajaran konvensional pada materi matriks. b) Siswa dengan self confidence tinggi, sedang dan rendah memiliki kemampuan pemecahan masalah matematis yang sama pada materi matriks. c) Pada model pembelajaran Missouri Mathematics Project dan pembelajaran konvensional, siswa dengan self confidence tinggi, sedang dan rendah memiliki kemampuan pemecahan masalah yang sama dalam materi matriks. d) Pada setiap kategori self confidence siswa, model pembelajaran Missouri Mathematics Project memberikan kemampuan pemecahan masalah matematis yang lebih baik daripada model pembelajaran konvensional.

\section{UCAPAN TERIMA KASIH}

Ucapan terima kasih disampaikan kepada lembaga yang telah mendukung terlaksananya penelitian ini. Ucapan terima kasih ditujukan kepada IKIP PGRI Pontianak, Dinas Pendidikan dan Kebudayaan Provinsi Kalimantan Barat, SMA Negeri 6 Pontianak.

\section{DAFTAR PUSTAKA}

Ansori, H., dan Aulia, I. (2015). Penerapan Model Pembelajaran Missouri Mathematics Project Terhadap Kemampuan Pemecahan Masalah Siswa di SMP. EDU-MAT Jurnal Pendidikan Matematika, 3(1), 49-58 
Arismawati, U., et all. (2017). Efektivitas Model Pembelajaran Problem Based Learning Ditinjau Dari Kemampuan Pemecahan Masalah dan Kepercayaan Diri Siswa Kelas VII SMP Negeri 1 Sanden. Jurnal Pendidikan Matematika, Vol. 6(9), Hal 9-19.

Budiyono. (2009). Statistik Untuk Penelitian. Surakarta: UPT. UNS Press.

Darma, Y. dan Sujadi, I. (2014). Strategi Heuristik dengan Pendekatan Metakognitif dan Investigasi Terhadap Kemampuan Pemecahan Masalah Matematis Ditinjau Dari Kreativitas Siswa Madrasah Aliyah. Jurnal Pendidikan Mipa, Vol. 15(2). Hal 110-119.

Hendriana, H., et all. (2018). Hard Skills dan Soft Skills Matematik Siswa. Bandung: PT. Refika Aditama.

Isrok'atun \& Rosmala, A. (2018). Model-Model Pembelajaran Matematika. Jakarta: PT. Bumi Aksara.

Sadat, Anwar. (2016). Implementasi Model Pembelajaran Missouri Mathematics Project Dalam Upaya Meningkatkan Kemampuan Pemecahan Masalah Matematis dan Self Confidence Siswa Madrasah Tsanawiyah. Jurnal pendidian Guru Sekolah Dasar, Vol. 2(1). Hal 1-11.

Siswono, E.Y. (2018). Pembelajaran Matematika Berbasis Pengajuan dan Pemecahan Masalah. Bandung: PT. Remaja Rosdakarya. 